\title{
Effect of potassium and sulfur on grain yield, oil concentration and fatty acid profile of sunflower
}

\author{
Saif Ullah ${ }^{1 *}$, Shazma Anwar ${ }^{1}$, Gul Roz Khan ${ }^{1}$, Muhammad Mehran \\ Anjum $^{1}$, Nawab Ali ${ }^{1}$, Abdul Jalal ${ }^{1}$, Kamran Ali ${ }^{1}$, Khaliq Uz Zaman ${ }^{1}$, \\ Muhammad Miraj ${ }^{2}$ and Amir Sohail ${ }^{3}$
}

1. Department of Agronomy, Faculty of Crop Production Sciences. The University of Agriculture, PeshawarPakistan

2. Department of Plant Breeding and Genetics, Faculty of Crop Production Sciences. The University of Agriculture, Peshawar-Pakistan

3. Department of Agriculture Chemistry, Faculty of Nutritional Sciences. The University of Agriculture, Peshawar-

Pakistan

*Corresponding author's email: saif2012aup@gmail.com

Citation

Saif Ullah, Shazma Anwar, Gul Roz Khan, Muhammad Mehran Anjum, Nawab Ali1, Abdul Jalal, Kamran Ali, Khaliq Uz Zaman, Muhammad Miraj and Amir Sohail. Effect of potassium and sulfur on grain yield, oil concentration and fatty acid profile of sunflower. Pure and Applied Biology. Vol. 8, Issue 1, pp139-150. http://dx.doi.org/10.19045/bspab.2018.700172

Received: 20/07/2018

Revised: 03/10/2018

Accepted: 22/10/2018

Online First: 25/10/2018

\section{Abstract}

Sunflower is an important edible oil seed crop. Adequate amount of nutrients are required for sunflower to get maximum yield. A field trial was conducted at Agronomy Research Farm, The University of Agriculture, Peshawar during Summer 2016 with the objective to investigate the effect of potassium levels $\left(30,60,90\right.$ and $\left.120 \mathrm{~kg} \mathrm{ha}^{-1}\right)$ and sulfur levels $\left(15,30,45\right.$ and $\left.60 \mathrm{~kg} \mathrm{ha}^{-1}\right)$ on oil and grain yield of sunflower. The experiment was conducted in randomized complete block (RCB) design with three replications. One control plot with no potassium and sulfur was maintained in each replication. Ammonium sulfate and Potassium chloride were applied as a source for sulfur and potassium, respectively. The results showed that palmitic acid concentration and stearic acid concentration were not affected by potassium and sulfur application. Potassium applied at the rate of $90 \mathrm{~kg} \mathrm{ha}^{-1}$ produced maximum biological yield (7178 $\left.\mathrm{kgha}^{-1}\right)$, grain yield $\left(2074 \mathrm{~kg} \mathrm{ha}^{-1}\right)$, oil yield $\left(775 \mathrm{~kg} \mathrm{ha}^{-1}\right)$, harvest index $(28.87 \%)$ and oil percentage (37.32 $\%)$. Sulfur applied at the rate of $60 \mathrm{~kg} \mathrm{ha}^{-1}$ produced maximum grains capitulum ${ }^{-1}$ (873), thousand grain weight (46.63 g), grain yield (2037 kg ha $\left.{ }^{-1}\right)$, oil yield $\left(771 \mathrm{~kg} \mathrm{ha}^{-1}\right)$, harvest index $(29.54 \%)$, oil percentage $(37.81 \%)$ and linoleic acid concentration $(78.80 \%)$. Non-significant effect of sulfur was observed on biological yield of sunflower. Application of potassium at the rate of $90 \mathrm{~kg} \mathrm{ha}^{-1}$ and sulfur at the rate of 60 $\mathrm{kg} \mathrm{ha}^{-1}$ could be recommended for higher oil and grain yield of sunflower.

Keywords: Capitulum; Linoleic acid; Oleic acid; Palmitic acid; Stearic acid

\section{Introduction}

Sunflower (Helianthus annuus L.) belongs to family Asteraceae. It is an essential oilseed crop. It is a potential remunerative crop due to its characters such as early maturity, adaptation to extensive climatic condition, soil and responsiveness to better production management practices. The oil of sunflower has a model combination of saturated and poly-unsaturated fatty acids, due to which it is 
considered very important in reducing of high serum cholesterol levels. Its oil cake contains protein in bulk amount around 40-44 percent [1]. The seed of sunflower have an adequate amount of oil approximately 35-40 \% while some varieties ranges up to $50 \%$ [2].

Sunflower was grown on an area of 0.5 million hectares with average yield of $1492 \mathrm{~kg}$ ha $^{-1}$ while in Khyber Pakhtunkhwa it was grown on an area of 0.001 million hectares $\mathrm{w}$ ith total yield obtained of 0.03 million tons and average yield $1620 \mathrm{~kg} \mathrm{ha}^{-1}$ [3]. The country total need of edible oil is approximately 3.07 million tons, of which 25 $\%$ (0.76 million tons) obtained from domestic cultivation [4]. The demand of palatable oil is met through imports. Pakistan is the third largest buyer of edible oil in the world and spends 1.2 billion dollar of annual budget on import of vegetable oils, which is a big crash to the economy of the country [5]. Many factor such as quality seeds, water and stimulant management, preparation of land etc. strongly affects production of crops. Among the other restrictions, one major constraint for low productivity of sunflower is imbalance use of fertilizers.

Fertilizer plays a vital role in the crop production. It's availability on time is very important for maximum yield production. The use of fertilizer needs to be made very wisely to avoid an adverse effect on the ecosystem. The fertilizer used in higher amount then required is extra financial burden on farmers [6]. The introduction of high yielding hybrids and their potential of utilizing fertilizers brought a significant depletion of nutrients from soil. The hybrids increased total yield with increase in crop nutritional requirements $[7,8]$. Potassium is one of the most essential elements for plant growth [9]. To improve quality of product and increase grain yield, crop requires potassium as high as nitrogen [8]. Potassium plays a major role in building resistance of crop to water stress, excess of temperature, salinity, pest and diseases [10].
The osmotic pressure provided by potassium that draws water into plant roots. Those plants which are deficient in $\mathrm{K}$ have less resistance to withstand water stress. It is because of their inability to utilize available water efficiently [11]. Potassium is used as a tool for maintaining internal salt meditation within cells and balance of water in the plant and operating closing and opening of stomata [12]. Potassium is also very important for activation of enzymes for photosynthesis, protein synthesis and starch formation [13].

Sulfur plays an important role for enhancing the seed and oil yield of sunflower. It is the fourth major nutrient used to get maximum crop production [14]. Many crops require sulfur in an equal amount as phosphorus. Its use in proper amount positively affects yield and quality of the crop. Sulfur increases the percentage of oil in seeds and plays an important role in chemical composition [15]. Sulfur is an ingredient of coenzymes, vitamins, biotin, thiamine and S-glycosides. It is an essential nutrient and plays important role in the expansion of plant, enzymes reactions, metabolism and key element of amino acids like cysteine and methionine [16]. The accessibility of sulfur in soil and its fertilization fluctuate its availability and uptake [17]. Sulfur deficiency in the soil increases with every next day due to the reason of severe consumption of low sulfur fertilizers, cultivation large number of crops in one season and also due to illogical use of plants for feed and fuel purpose. Erosion and leaching degraded the soil, which also donate their part in enhancing the areas have deficient in sulfur [18]. Furthermore, oilseed crops require sulfur in large amount as compare to other crops. [19] Reported that a young plant of sunflower requires sulfur in higher amount to harvest heavier heads and highest leaf area.

Keeping in view the importance of sunflower crop for oil production, the present study was conducted to find out the optimum potassium 
and sulfur levels for higher yield of sunflower for the agro-climatic conditions of Peshawar valley.

\section{Materials and methods}

Effect of potassium and sulfur on oil and grain yield of sunflower was evaluated at Agronomy Research Farm, The University of Agriculture Peshawar during summer 2016. The experiment was carried out in randomized complete block (RCB) design with three replications. Four levels of potassium $(\mathrm{K})$ and four levels of sulfur (S) were used in the experiment. One control plot with no application of potassium and sulfur was maintained in each replication. Ammonium sulfate $\left(\mathrm{NH}_{4}\right) 2 \mathrm{SO}_{4}$ and Muriate of potash $(\mathrm{KCl})$ was used as a source of sulfur and potassium respectively. Sunflower hybrid "Hysun 33" was used as a test crop. Plot size of $3 \mathrm{~m} \times 3.5 \mathrm{~m}$, having 5 rows with row to row distance of $70 \mathrm{~cm}$ was maintained. Recommended rate of nitrogen (N) $\left(90 \mathrm{~kg} \mathrm{ha}^{-}\right.$ $\left.{ }^{1}\right)$ and phosphorus (P) (60 kg ha-1) was applied. All the agronomic practices were maintained uniformly for all the experimental units.

Following factors and their levels were studied in the experiment.

\section{Factor $\mathbf{A}=$ Potassium $(\mathrm{K})$ levels $\left(\mathrm{kg} \mathrm{ha}^{-1}\right)$}

$\mathrm{K}_{1}=30$

$\mathrm{K}_{2}=60$

$\mathrm{K}_{3}=90$

$\mathrm{K}_{4}=120$

Factor $B=$ Sulfur $(S)$ levels $\left(\mathrm{kg} \mathrm{ha}^{-1}\right)$

$\mathrm{S}_{1}=15$

$\mathrm{S}_{2}=30$

$\mathrm{S}_{3}=45$

$\mathrm{S}_{4}=60$

Data were recorded on the following parameters

1. Number of grains capitulum ${ }^{-1}$

2. Thousand grain weight $(\mathrm{g})$

3. Biological yield $\left(\mathrm{kg} \mathrm{ha}^{-1}\right)$

4. Grain yield $\left(\mathrm{kg} \mathrm{ha}^{-1}\right)$

5. Oil yield $\left(\mathrm{kg} \mathrm{ha}^{-1}\right)$

6. Harvest index (\%)

7. Oil percentage $(\%)$
8. Oleic acid concentration (\%)

9. Linoleic acid concentration (\%)

10. Palmitic acid concentration (\%)

11. Stearic acid concentration (\%)

Number of grains capitulum ${ }^{-1}$

The data were noted at harvesting stage by recording the number of grains from randomly selected 10 heads in each plot and then recorded data were averaged.

Thousand grain weight (g)

From the seed lot of every plot, thousand grains were randomly counted, weighted in grams (g) and averaged.

\section{Single seed weight (g)}

The weight of single seed capitula ${ }^{-1}$ is secondary data derived from primary data of thousand grain weight.

Biological yield $\left(\mathrm{kg} \mathrm{ha}^{-1}\right)$

The biological yield was noticed by harvesting three central rows from each plot. The material was sun dried, weighed and converted into $\mathrm{kg} \mathrm{ha}^{-1}$.

\section{Grain yield (kg ha-1)}

The plants harvested from three central rows in each plot were threshed, cleaned, sun dried, weighed and converted the recorded data of each experimental unit into $\mathrm{kg} \mathrm{ha}^{-1}$.

Oil yield ( $\left.\mathrm{kg} \mathrm{ha}^{-1}\right)$

Oil content (\%) determined for each experimental unit was multiplied with seed yield of respective plot to compute the oil yield on $\mathrm{kg} \mathrm{ha}^{-1}$ basis.

\section{Harvest index (\%)}

Harvest index was calculated by dividing the total grain yield by biological yield multiplied with 100.

\section{Oil percentage $(\%)$}

Oil content in grains was analyzed by Sochlet Fat Extraction method [20] in The University of Agriculture Peshawar. First of all round bottom flask was weighted (W1) and filled with $1 / 3$ petroleum ether. The moisture free sample (grinded grain) was wrapped in filter paper and placed in thimble in the extraction tube of Sochlet fat extraction machine. Water is flowed carefully for condensation and 
burner is turned on for evaporation, the process continues until all the ether evaporates and oil settled down in the bottom of round bottom flask. Flask is cool down in desiccator for 20 minutes and then weighted the flask again after cooling (W2). The collected data was used to calculate oil percentage of each grain sample.

\section{Achene fatty acid profile (\%)}

Fatty acids profile were recorded by Gas Liquid Chromatography (GLC) in the Lab of University of Agriculture Peshawar. By chromatography we separated mixture of chemicals (oil) which were in a liquid form by letting them creped, slowly past another substances (oil liquid). The mobile phase moved and separated out into its component (oleic acid, linoleic acid, palmitic acid and stearic acid).

\section{Statistical analysis}

Data were analyzed statistically using analysis of variance techniques appropriate for randomized complete block design. Means were compared using LSD test at 0.05 level of probability, when the F-values are significant [21].

\section{Results}

\section{Number of grains capitulum ${ }^{-1}$}

Table 1 presents data regarding number of grains capitulum ${ }^{-1}$ of sunflower as enhanced by potassium and sulfur fertilization. Statistical analysis of the data showed that potassium and sulfur significantly affected number of grains capitulum ${ }^{-1}$. The interaction of $\mathrm{K}$ and $\mathrm{S}$ was also found significant. Application of $\mathrm{K}$ at the level of $90 \mathrm{~kg} \mathrm{ha}^{-1}$ gave maximum (892) grains capitulum ${ }^{-1}$ which was statistically at par with $120 \mathrm{~kg} \mathrm{ha}^{-1}$ while minimum (791) grains head ${ }^{-1}$ were recorded with $30 \mathrm{~kg} \mathrm{ha}^{-1}$. Data regarding sulfur showed that maximum (873) number of grains capitulum $^{-1}$ were noticed in plots where $S$ embedded at the rate of $60 \mathrm{~kg} \mathrm{ha}^{-1}$ while minimum number of grains capitulum ${ }^{-1}$ (836) were noticed at $15 \mathrm{~kg} \mathrm{~S} \mathrm{ha}^{-1}$. Interaction of $\mathrm{K}$ and $\mathrm{S}$ indicated that combine application of potassium and sulfur increased number of grains capitulum ${ }^{-1}$. Plots that received no potassium and sulfur resulted in minimum grains capitulum $^{-1}$ (731) as compared to rest of treatments (854).

\section{Thousand grain weight $(\mathrm{g})$}

Data pertaining to the impact of potassium and sulfur on thousand grain weight of sunflower is presented in Table 1. It is evident from the statistical analysis of the data that potassium and sulfur levels showed significant variation in thousand grain weight of sunflower. Similarly the interaction of K and $\mathrm{S}$ was also found significant. Plots fertilized with $\mathrm{K}$ at the rate of $90 \mathrm{~kg} \mathrm{ha}^{-1}$ produced heavier (46.43 g) grains which was statistically at par with 60 and $120 \mathrm{~kg} \mathrm{ha}^{-1}$ while lighter ( $44.55 \mathrm{~g})$ grains were noted with $30 \mathrm{~kg} \mathrm{~K} \mathrm{ha}^{-1}$ application. Sulfur application at the rate of $60 \mathrm{~kg} \mathrm{ha}{ }^{-1}$ resulted in higher thousand grain weight (46.63 g) which did not differ with $45 \mathrm{~kg} \mathrm{~S} \mathrm{ha}^{-1}$ while lower thousand grain weight (44.96 g) was recorded with 15 $\mathrm{kg} \mathrm{S} \mathrm{ha}{ }^{-1}$. In case of $\mathrm{K}$ and $\mathrm{S}$ interaction, increase in grain weight was observed with increase in $\mathrm{S}$ levels. The planned mean comparison of control vs. rest showed that control plots resulted in lighter grains (33.01 $\mathrm{g})$ as compared to treated plots (45.83 g).

\section{Biological yield ( $\mathrm{kg} \mathrm{ha}^{-1}$ )}

Significant variation in biological yield of sunflower was recorded by potassium application presented in (Table 1). Sulfur effect was found non-significant while $\mathrm{K}$ x S was significant. Maximum biological yield $\left(7178 \mathrm{~kg} \mathrm{ha}^{-1}\right)$ was noted in plots where $\mathrm{K}$ was incorporated at the rate of $90 \mathrm{~kg} \mathrm{ha}^{-1}$ and minimum biological yield (6485 $\mathrm{kg} \mathrm{ha}^{-1}$ ) was recorded in plots fertilized with $30 \mathrm{~kg} \mathrm{~K} \mathrm{ha}^{-1}$ (Fig. 1). The interaction of $\mathrm{K}$ and $\mathrm{S}$ revealed that combined application of potassium and sulfur increased biological yield. The planned mean comparison of control with rest showed that control plots produced lower biological yield $\left(6156 \mathrm{~kg} \mathrm{ha}^{-1}\right)$ in comparison to treated plots $\left(6860 \mathrm{~kg} \mathrm{ha}^{-1}\right)$. 


\section{Grain yield ( $\left.\mathrm{kg} \mathrm{ha}^{-1}\right)$}

Potassium, sulfur and $\mathrm{K} \times \mathrm{S}$ significantly affected grain yield of sunflower revealed in (Table 1). In case of potassium maximum grain yield (2074 $\mathrm{kg} \mathrm{ha}^{-1}$ ) was calculated in plots where $\mathrm{K}$ was incorporated at the rate of $90 \mathrm{~kg} \mathrm{ha}^{-1}$ which was statistically at par with $120 \mathrm{~kg} \mathrm{ha}^{-1}$ whereas minimum grain yield $\left(1764 \mathrm{~kg} \mathrm{ha}^{-1}\right)$ was produced in plots where potassium was incorporated at the rate of 30 $\mathrm{kg} \mathrm{ha}^{-1}$. Sulfur fertilization at the rate of $60 \mathrm{~kg}$ $\mathrm{ha}^{-1}$ gave higher grain yield (2037 $\mathrm{kg} \mathrm{ha}^{-1}$ ) which did not differ statistically with $45 \mathrm{~kg}$ $\mathrm{ha}^{-1}$ while lowest yield (1882 $\mathrm{kg} \mathrm{ha}^{-1}$ ) was noted in plots where sulfur was embedded at the rate of $15 \mathrm{~kg} \mathrm{ha}^{-1}$ (Fig. 1). The interaction of $\mathrm{K}$ and $\mathrm{S}$ showed that combined fertilization of potassium and sulfur increased grain yield. The fertilized plots produced significantly higher grain yield (1961 kg ha' $\mathrm{kg}^{-1}$ than control (1207 kg ha-1).

\section{Oil yield ( $\left.\mathrm{kg} \mathrm{ha}^{-1}\right)$}

Data related to oil yield $\left(\mathrm{kg} \mathrm{ha}^{-1}\right)$ of sunflower is presented in (Table 1). Statistical analysis of the data revealed that potassium, sulfur and $\mathrm{K} x \mathrm{~S}$ significantly affected oil yield. More oil yield $\left(838 \mathrm{~kg} \mathrm{ha}^{-1}\right)$ was noticed in plots where $\mathrm{K}$ was incorporated at the level of $90 \mathrm{~kg} \mathrm{ha}^{-1}$ while less oil yield $\left(643 \mathrm{~kg} \mathrm{ha}^{-1}\right)$ was noticed in plots treated with $30 \mathrm{~kg} \mathrm{~K} \mathrm{ha}^{-1}$. Maximum oil yield $\left(771 \mathrm{~kg} \mathrm{ha}^{-1}\right)$ was observed in plots fertilized with sulfur at the level of $60 \mathrm{~kg} \mathrm{ha}^{-}$ 1 . As decrease in sulfur level occurred, decline in oil yield was noticed and minimum oil yield (666 kg ha-1) was calculated in plots where sulfur was incorporated at the rate of 15 $\mathrm{kg} \mathrm{ha}^{-1}$. The interaction of $\mathrm{K}$ and $\mathrm{S}$ showed that combined incorporation of potassium and sulfur increased oil yield (Fig. 1). The planned mean comparison of control with rest of treatments revealed that control plots produced lower oil yield (392 $\mathrm{kg} \mathrm{ha}^{-1}$ ) as compared to treated plots $\left(720 \mathrm{~kg} \mathrm{ha}^{-1}\right)$.

\section{Harvest index (\%)}

It was revealed from statistical analysis of the data that potassium and sulfur significantly influenced harvest index of sunflower reported in (Table 1). The interaction of $\mathrm{K}$ and $\mathrm{S}$ was also found significant. Maximum harvest index $(29.20 \%)$ was recorded where potassium was embedded at the rate of $60 \mathrm{~kg}$ $\mathrm{ha}^{-1}$ which was statistically at par with $120 \mathrm{~kg}$ $\mathrm{K} \mathrm{ha}^{-1}$, while minimum harvest index (27.19 $\%$ ) was calculated in plots where $\mathrm{K}$ was incorporated at the rate of $30 \mathrm{~kg} \mathrm{ha}^{-1}$. Among the sulfur treated plots, maximum harvest index $(29.54 \%)$ was noticed in plots where sulfur was embedded at the level of $60 \mathrm{~kg} \mathrm{ha}^{-}$ ${ }^{1}$ which was statistically at par with $45 \mathrm{~kg}^{-}$ ${ }^{1}$. Lower harvest index $(27.64 \%)$ was marked with $15 \mathrm{~kg} \mathrm{~S} \mathrm{ha}^{-1}$. The treated plots produced significantly maximum harvest index (28.59 $\%)$ than control $(19.60 \%)$.

\section{Oil percentage $(\%)$}

Statistical analysis of the data showed that application of sulfur and potassium had significantly affected oil percentage of sunflower expressed in (Table 2) while the interaction of $\mathrm{K}$ and $\mathrm{S}$ remained nonsignificant. In case of potassium, higher oil \% (37.32) was noticed in plots where $\mathrm{K}$ was incorporated at level of $90 \mathrm{~kg} \mathrm{ha}^{-1}$ while the lower oil \% (36.23) was recorded in plots where potassium was incorporated at the rate of $120 \mathrm{~kg} \mathrm{ha}^{-1}$ which was statistically at par with $30 \mathrm{~kg} \mathrm{ha}^{-1}$. Sulfur application at the rate of $60 \mathrm{~kg} \mathrm{ha}^{-1}$ gave maximum oil \% (37.81) while minimum oil \% (35.45) was noted in plots where sulfur was embedded at the rate of $15 \mathrm{~kg} \mathrm{ha}^{-1}$ (Fig. 2). Data regarding K x S revealed that the interaction caused increase in oil concentration with increase in sulfur levels. The data showed that treated plots produced significantly higher oil \% (36.73) than control plots (31.77\%). 
Table 1. Grains Capitulum ${ }^{-1}$, thousand grain weight (g), Biological yield $\left(\mathrm{kg} \mathrm{ha}^{-1}\right)$, Grain yield $\left(\mathrm{kg} \mathrm{ha}^{-1}\right)$, Oil yield $\left(\mathrm{kg} \mathrm{ha}^{-1}\right)$ and Harvest index $(\%)$ as affected by potassium and sulfur levels

\begin{tabular}{|c|c|c|c|c|c|c|}
\hline Treatment & $\begin{array}{c}\text { Number of } \\
\text { Grains } \\
\text { capitulum }\end{array}$ & $\begin{array}{c}\text { Thousand } \\
\text { Grain weight }\end{array}$ & $\begin{array}{c}\text { Biological } \\
\text { Yield }\end{array}$ & $\begin{array}{c}\text { Grain } \\
\text { Yield }\end{array}$ & Oil Yield & $\begin{array}{c}\text { Harvest } \\
\text { Index }\end{array}$ \\
\hline & & $(\mathrm{g})$ & $\left(\mathrm{kg} \mathrm{ha}^{-1}\right)$ & $\left(\mathrm{kg} \mathrm{h}^{-1}\right)$ & $\left(\mathrm{kg} \mathrm{ha}^{-1}\right)$ & $(\%)$ \\
\hline A: Potassium $\left(\mathrm{kg} \mathrm{ha}^{-1}\right)$ & & & & & & \\
\hline 30 & $791 \mathrm{c}$ & $44.55 \mathrm{~b}$ & $6485 \mathrm{~d}$ & $1764 \mathrm{c}$ & $643 \mathrm{~d}$ & $27.19 \mathrm{~b}$ \\
\hline 60 & $848 \mathrm{~b}$ & $45.97 \mathrm{a}$ & $6680 \mathrm{c}$ & $1951 \mathrm{~b}$ & $721 \mathrm{c}$ & $29.20 \mathrm{a}$ \\
\hline 90 & $892 \mathrm{a}$ & $46.43 \mathrm{a}$ & $7178 \mathrm{a}$ & $2074 \mathrm{a}$ & $775 \mathrm{a}$ & $28.86 \mathrm{a}$ \\
\hline 120 & $886 \mathrm{a}$ & $46.36 \mathrm{a}$ & $7083 \mathrm{~b}$ & $2056 \mathrm{a}$ & $743 \mathrm{~b}$ & $29.11 \mathrm{a}$ \\
\hline LSD $(\mathrm{P} \leq 0.05)$ & 20.51 & 0.53 & 88.93 & 45.68 & 18.95 & 0.72 \\
\hline B: Sulfur $\left(\mathrm{kg} \mathrm{ha}^{-1}\right)$ & & & & & & \\
\hline 15 & $836 \mathrm{c}$ & $44.95 \mathrm{c}$ & 6796 & $1882 \mathrm{c}$ & $666 \mathrm{~d}$ & $27.64 \mathrm{~b}$ \\
\hline 30 & $846 \mathrm{bc}$ & $45.56 \mathrm{~b}$ & 6863 & $1930 \mathrm{~b}$ & $703 \mathrm{c}$ & $28.11 \mathrm{~b}$ \\
\hline 45 & $863 \mathrm{ab}$ & $46.17 \mathrm{a}$ & 6878 & $1995 \mathrm{a}$ & $741 \mathrm{~b}$ & $29.07 \mathrm{a}$ \\
\hline 60 & $873 \mathrm{a}$ & $46.62 \mathrm{a}$ & 6889 & $2037 \mathrm{a}$ & $771 \mathrm{a}$ & $29.53 \mathrm{a}$ \\
\hline LSD $(\mathrm{P} \leq 0.05)$ & 20.51 & 0.53 & $\mathrm{NS}$ & 45.68 & 18.95 & 0.72 \\
\hline Control & $731 \mathrm{~b}$ & $33.01 \mathrm{~b}$ & $6156 \mathrm{~b}$ & $1207 \mathrm{~b}$ & $392 \mathrm{~b}$ & $19.60 \mathrm{~b}$ \\
\hline Rest & $854 \mathrm{a}$ & $45.83 \mathrm{a}$ & $6857 \mathrm{a}$ & $1961 \mathrm{a}$ & $720 \mathrm{a}$ & $28.59 \mathrm{a}$ \\
\hline C: Interaction $(\mathrm{KxS})$ & & & & & & \\
\hline LSD $(\mathrm{P} \leq 0.05)$ & 41.03 & 1.06 & 177.86 & 91.37 & 37.9 & 1.44 \\
\hline
\end{tabular}

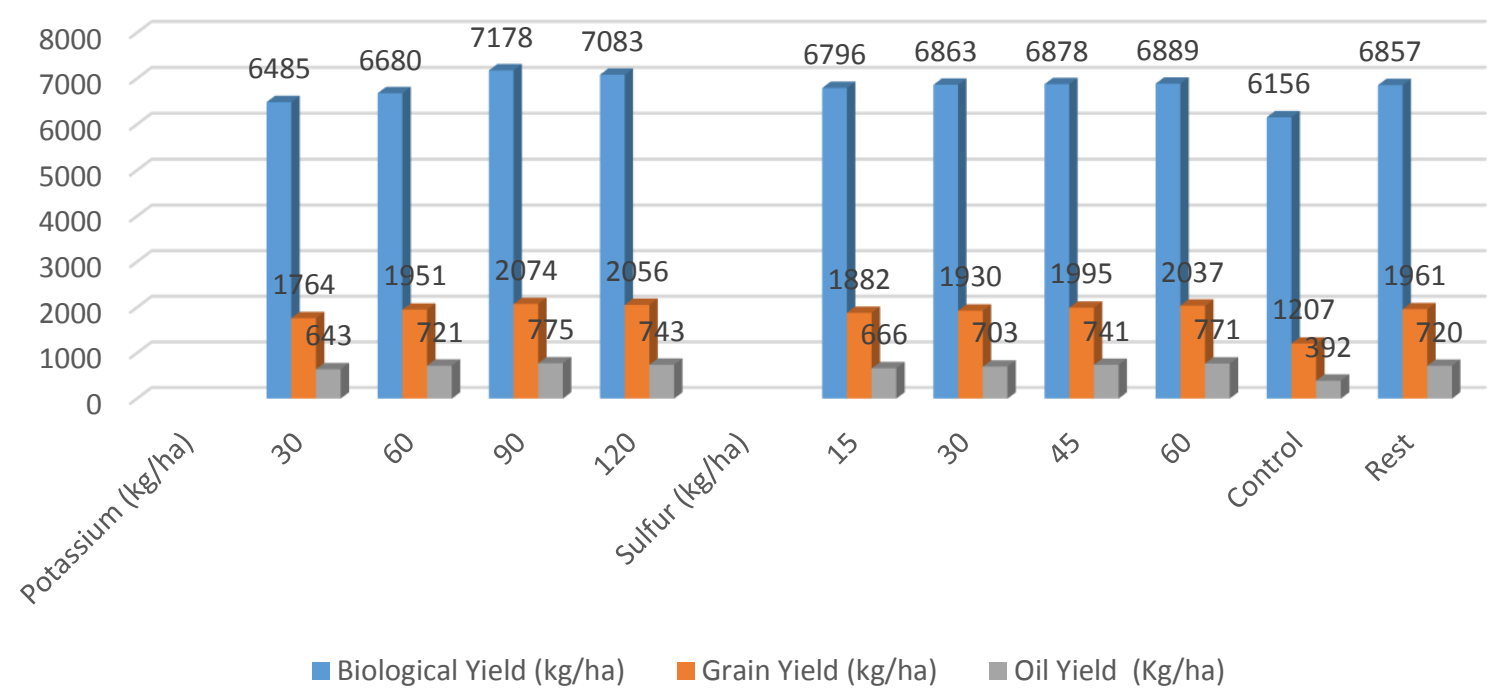

Figure 1. Biological yield, Grain yield and Oil yield as affected by potassium and sulfur fertilization

Oleic acid concentration $(\%)$

Data related oleic acid concentration as effected by potassium and sulfur is presented in (Table 2). Sulfur had significant effect on oleic acid concentration while potassium and interaction of $\mathrm{K}$ and $\mathrm{S}$ remained non- 
significant. Oleic acid concentration decreased as amount of sulfur increase, maximum $(12.51 \%)$ oleic acid was found with $15 \mathrm{~kg} \mathrm{~S} \mathrm{ha}^{-1}$ while minimum concentration $(11.31 \%)$ was recorded with $60 \mathrm{~kg} \mathrm{ha}^{-1}$ (Figure 3). Treated plots had minimum (11.91\%) oleic acid concentration than control (12.53\%).

\section{Linoleic acid concentration (\%)}

Significant variation in linoleic acid concentration of sunflower oil was recorded by sulfur application expressed in (Table 2). The effect of potassium and interaction of $\mathrm{K}$ and $\mathrm{S}$ was found non-significant. Higher (78.80\%) linoleic acid concentration was recorded in plots fertilized with $60 \mathrm{~kg} \mathrm{~S}^{-1}$ as amount of sulfur increased an increase in linoleic acid concentration was found while minimum $(75.71 \%)$ concentration was recorded with $15 \mathrm{~kg} \mathrm{~S}^{-1}$ (Fig. 3). The result showed that treated plots had maximum (77.41\%) linoleic acid concentration then control (74.33\%).

\section{Palmitic acid concentration (\%)}

Data regarding palmitic acid concentration is reported in (Table 2). The results revealed that both potassium and sulfur had nonsignificant effect on palmitic acid concentration (Figure 3). The interaction of $\mathrm{K}$ and $\mathrm{S}$ was also found non-significant.

Stearic acid concentration (\%)

Statistical analysis of the data is presented in (Table 2) indicated that application of potassium and sulfur had non-significant effect on stearic acid concentration (Figure $3)$. The interaction of $\mathrm{K}$ and $\mathrm{S}$ also remained non-significant.

\section{Discussion}

In the light of literature accumulated, our results of different parameters are briefly elaborated in this chapter.Yield parameters like number of grains capitulum ${ }^{-1}$ was improved by both potassium and sulfur.
Number of grains were maximum at $90 \mathrm{~kg} \mathrm{~K}$ $\mathrm{ha}^{-1}$ and $60 \mathrm{~kg} \mathrm{~S} \mathrm{ha}^{-1}$. The maximum number of grains capitulum ${ }^{-1}$ was due to maximum head diameter. [23] Stated that number of grains head ${ }^{-1}$ was totally dependent on disc area as larger will be the disc more number of grains will be grown. [10] Noticed a significant effect of sulfur fertilization on number of grains head ${ }^{-1}$ in sunflower. The conclusion of [16] are in support of our findings, that sulfur application helps in the expansion of plant as a result sunflower produced larger disc which produce maximum number of grains thus achieved more grain yield. Maximum number of grains head $^{-1}$ was noticed when potassium was incorporated at the rate of 90 and sulfur $60 \mathrm{~kg}$ $\mathrm{ha}^{-1}$ [25].

Statistical analysis of the data indicated that increase in thousand grain weight and single seed weight capitula ${ }^{-1}$ occurred with increase in potassium and sulfur levels. Maximum grain weight was achieved in plots where potassium and sulfur was embedded at the rate of $90 \mathrm{~kg} \mathrm{ha}^{-1}$ and $60 \mathrm{~kg} \mathrm{ha}^{-1}$ respectively. [24] Stated that optimum amount of potassium supply enhanced the grain filling period which leaded to increase in wheat grain weight. The optimum level of potassium for sunflower maximum grain weight was $80-100 \mathrm{~kg} \mathrm{~K} \mathrm{ha}^{-1}$, over this level the application of potassium was not economical. [26] Stated that thousand grain weight enhanced rapidly with the incorporation of potassium fertilizer. The maximum thousand grain weight achieved with $60 \mathrm{~kg} \mathrm{~S} \mathrm{ha}^{-1}$ might be due to the optimum acquisition of different nutrient elements in the grain caused an increase in grain weight. Our result is in accordance with the findings of other authors $[27,28]$. who found a positive response of grain to sulfur application in sunflower. 
Table 2. Oil percentage (\%), Oleic acid concentration (\%), Linoleic acid concentration (\%), Palmitic acid concentration $(\%)$ and Stearic acid concentration $(\%)$ as affected by potassium and sulfur levels

\begin{tabular}{|c|c|c|c|c|c|}
\hline Treatment & $\begin{array}{c}\text { Oil } \\
\text { Percentage }\end{array}$ & Oleic Acid & Linoleic Acid & Palmitic Acid & Stearic Acid \\
\hline & $(\%)$ & $\begin{array}{c}\text { Concentration } \\
(\%)\end{array}$ & $\begin{array}{c}\text { Concentration } \\
(\%)\end{array}$ & $\begin{array}{c}\text { Concentration } \\
(\%)\end{array}$ & $\begin{array}{c}\text { Concentration } \\
(\%)\end{array}$ \\
\hline \multicolumn{6}{|c|}{$\begin{array}{c}\text { A: Potassium (kg } \\
\left.\text { ha }^{-1}\right)\end{array}$} \\
\hline 30 & $36.45 \mathrm{c}$ & 11.90 & 77.27 & 5.10 & 4.06 \\
\hline 60 & $36.90 \mathrm{~b}$ & 11.99 & 77.31 & 4.89 & 4.07 \\
\hline 90 & $37.31 \mathrm{a}$ & 11.75 & 77.58 & 5.00 & 4.06 \\
\hline 120 & $36.22 \mathrm{c}$ & 11.99 & 77.48 & 4.82 & 3.88 \\
\hline LSD (0.05) & 0.39 & NS & NS & NS & NS \\
\hline \multicolumn{6}{|c|}{ B: Sulfur (kg ha $\left.{ }^{-1}\right)$} \\
\hline 15 & $35.45 \mathrm{~d}$ & $12.51 \mathrm{a}$ & $75.70 \mathrm{c}$ & 4.90 & 3.91 \\
\hline 30 & $36.49 \mathrm{c}$ & $12.15 \mathrm{a}$ & $76.94 \mathrm{~b}$ & 4.92 & 4.05 \\
\hline 45 & $37.15 \mathrm{~b}$ & $11.65 \mathrm{~b}$ & $78.19 \mathrm{a}$ & 4.95 & 4.11 \\
\hline 60 & $37.81 \mathrm{a}$ & $11.30 \mathrm{c}$ & $78.79 \mathrm{a}$ & 5.04 & 3.99 \\
\hline LSD (0.05) & 0.39 & 0.2 & 0.53 & NS & NS \\
\hline Control & $31.76 \mathrm{~b}$ & $12.52 \mathrm{a}$ & $74.33 \mathrm{~b}$ & 4.63 & 3.81 \\
\hline Rest & $36.72 \mathrm{a}$ & $11.90 \mathrm{~b}$ & $77.40 \mathrm{a}$ & 4.95 & 4.01 \\
\hline \multicolumn{6}{|l|}{$\begin{array}{c}\text { C: Interaction } \\
(\mathbf{K} \times \mathbf{S})\end{array}$} \\
\hline LSD (0.05) & 0.78 & NS & NS & NS & NS \\
\hline
\end{tabular}

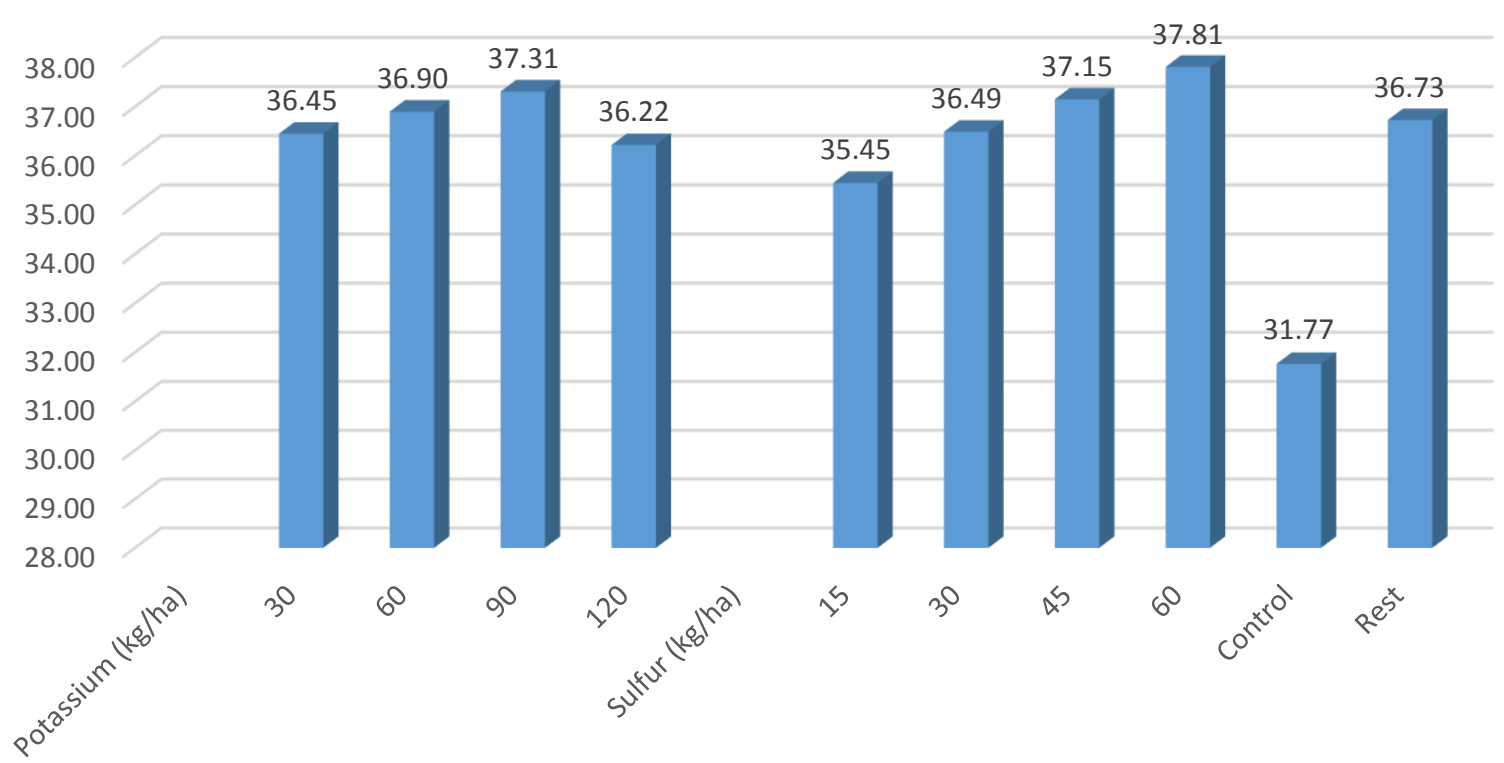

Figure 2. Oil percentage $(\%)$ of sunflower as affected by potassium and sulfur fertilization 


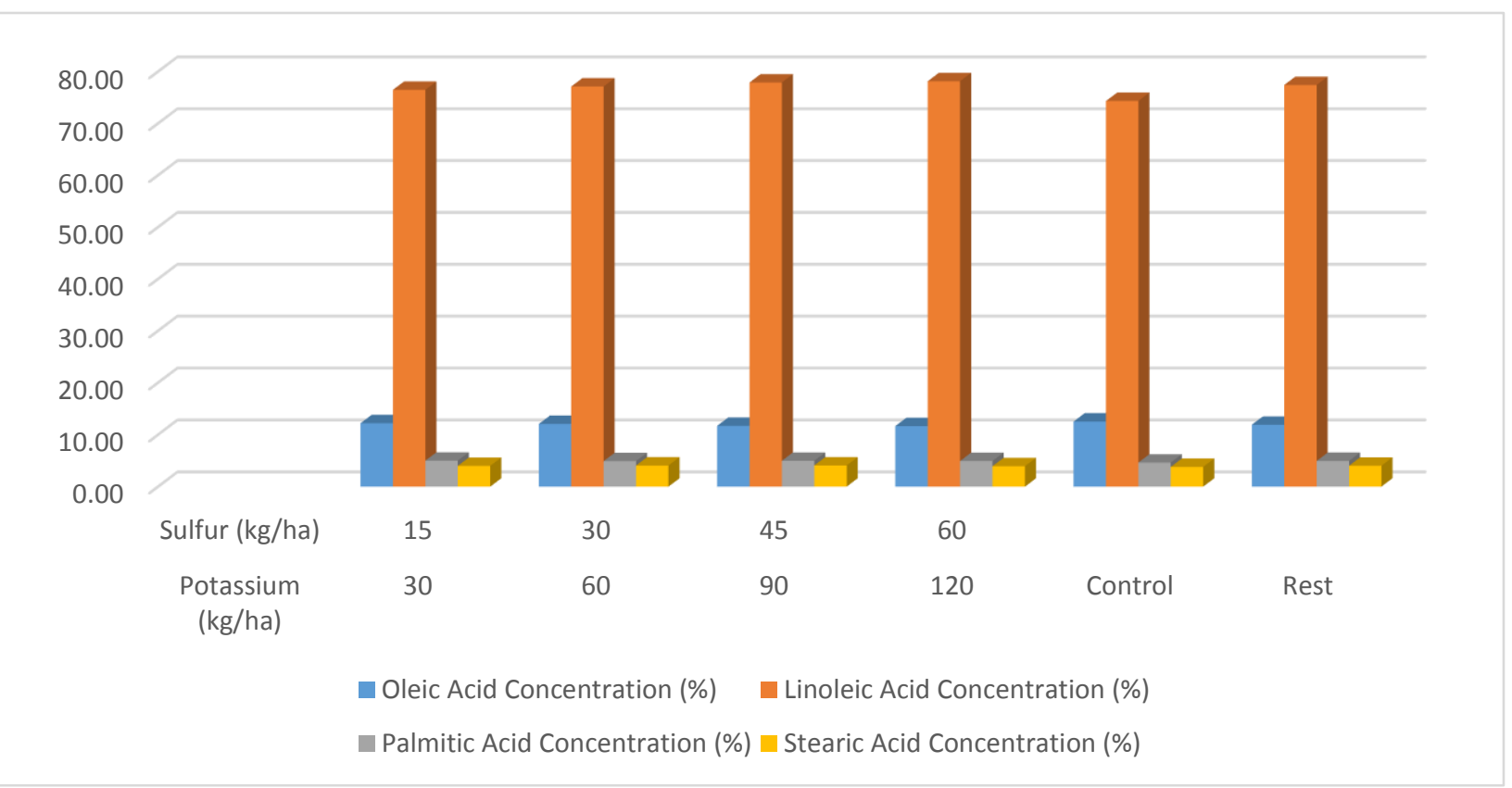

Figure 3. Fatty acid profile of sunflower as affected by potassium and sulfur fertilization

Biological yield of sunflower was significantly increased by $\mathrm{K}$ levels. Maximum biological yield was produced when potassium was incorporated up to $90 \mathrm{~kg}$ $\mathrm{ha}^{-1}$. Our results are in lines with conclusion of [29] who revealed that potassium increased the stem girth, stalk yield and biological yield. The probable reason for accretion in biological yield might be due to potassium augmented the rate of $\mathrm{CO}_{2}$ assimilation, stabilization of stomata regulation and activate enzymes that results in more carbohydrates formation, which may cause an increase in biological yield. The conclusion are in lines with the investigation of [30] who observed that increasing potassium amount expedited carbohydrate production in plant and finally led to improving biological yield.

Grain yield of sunflower was significantly increased by potassium and sulfur up to $90 \mathrm{~kg}$ $\mathrm{ha}^{-1}$ and $45 \mathrm{~kg} \mathrm{ha}^{-1}$ respectively. The probable reason for high grain yield might be due to that potassium boosted the chlorophyll content, increased in leaf area, maximum number of grains per capitulum and heavier thousand grain weight. The results are in conformity with findings of [31] who revealed that final grain yield was the end product of all the yield components which are influenced by a particular set of climatic conditions and fertilizers applied. Our results are in lines with [14] that increasing levels of sulfur application enhanced grain yield. [32] Stated that sulfur and potassium levels crossed to expedite the efficiency of the plant and in results high grain yield was obtained. Harvest index of sunflower was significantly increased by potassium and sulfur fertilization up to $90 \mathrm{~kg} \mathrm{ha}^{-1}$ and $45 \mathrm{~kg} \mathrm{ha}^{-1}$ respectively. The probable reason for increased in harvest index might be due to increase in grain yield $\mathrm{kg} \mathrm{ha}^{-1}$ same in lines with [10] who observed that $\mathrm{K}$ incorporation of $100 \mathrm{~kg} \mathrm{ha}^{-1}$ and sulfur $40 \mathrm{~kg} \mathrm{ha}^{-1}$ had significant effect on harvest index. It might be due to more assimilates partitioning with the application of high level of potassium and sulfur which resulted greater grain yield in sunflower.

The consummate objective in the production of oilseed crops is the oil yield which is the 
end product of grain yield in case of sunflower. Data showed a positive influence of potassium application on oil $\%$ and oil yield $\mathrm{kg} \mathrm{ha}^{-1}$. Higher grain oil $\%$ and oil yield $\mathrm{kg} \mathrm{ha}^{-1}$ was noticed with the fertilization of $\mathrm{K}$ at $90 \mathrm{~kg} \mathrm{ha}^{-1}$, further increased in potassium level reduced the oil concentration. The results might be due to the fact that $\mathrm{K}$ is used as a tool to activate enzymes for photosynthesis, starch formation and protein synthesis and to improve oil concentration and quality, but when potassium exceeds from a certain limit it may break enzymes and reduce the oil concentration. Similar results are stated by [30] who stated that potassium fertilizers had significant impact on seed oil content and caused variation in yield. Generally results indicated that use of potassium fertilizers improves both the qualitative and quantitative characteristics of sunflower but to use potassium in excessive amount is not wise and cause degradation of enzymes these are also in line with the finding of [11].

The boosting trend of oil amount with sulfur fertilization in present experiment was observed and maximum oil yield $\mathrm{kg} \mathrm{ha}^{-1}$ and oil percentage along with unsaturated fatty acid were obtained on $60 \mathrm{~kg} \mathrm{ha}^{-1}$. The results might be due to that sulfur is an ingredient of S-glycosides, coenzymes, vitamins, biotin and thiamine. It is an essential nutrients and play important role in plant expansion, enzymatic reactions metabolism, and main element of sulfur containing amino acids like cysteine and methionine which accelerate the oil production in seeds. [32] Reported that sulfur application helped in conversion of carbohydrates into oil. In fatty acid formation, acetyl co-A was changed into malonyl co-A. In this transfiguration an enzyme thiokinase is involved, the activation of which totally depends upon sulfur supply. Moreover, acetyl co-A itself contains sulfur and sulfhydryl group.
The properties of sulfur indicated that when it is applied to the soil, absorbs moisture and disintegrates into fine and coarse particles. The finer particles oxidize rapidly which might have supplied sufficient sulfur to the soil pool throughout the growth period of sunflower and resulted in higher seed yield. The accessibility of sulfur in soil and its fertilization fluctuate its availability and uptake [26].

\section{Conclusion}

It is concluded from this study that application of $90 \mathrm{~kg} \mathrm{~K} \mathrm{ha}^{-1}$ and $60 \mathrm{~kg} \mathrm{~S} \mathrm{ha}^{-1}$ performed better in terms of growth and yield as compared to rest. Potassium and sulfur at $90 \mathrm{~kg} \mathrm{ha}^{-1}$ and $60 \mathrm{~kg} \mathrm{ha}^{-1}$ respectively significantly enhanced plant height, number of leaves plant ${ }^{-1}$, head diameter, number of grains head ${ }^{-1}$, thousand grain weight, biological yield, grain yield, oil \% and oil yield. Based on the findings of our results application of potassium at the rate of $90 \mathrm{~kg}$ $\mathrm{ha}^{-1}$ and sulfur at the rate of $60 \mathrm{~kg} \mathrm{ha}^{-1}$ could be recommended for higher oil and grain yield of sunflower in agro climatic conditions of Peshawar valley.

\section{Authors' contributions}

Conceived and designed the experiments: $S$ Ullah \& S Anwar, Performed the experiment: S Ullah, MM Anjum, N Ali, M Miraj, K Ali \& KU Zaman, Analyzed the data: S Ullah, GR Khan \& A Jalal, Contributed reagents/ materials/ analysis tools: S Ullah, S Anwar \& Amir Sohail, Wrote the paper: S Ullah.

\section{References}

1. Balasubramaniyan $P$ \& Palaniappan SP (2001). Principles and Practices of Agronomy. Agrobios. $2^{\text {nd }}$ Edition pp 185-188.

2. MNFSR (2014-2015). Ministry of National Food Security and Research Islamabad Pakistan.

3. Nasreen S \& Imamulhaq SM (2002). Effect of sulfur fertilizer on yield and nutrient uptake of sunflower crop in an 
Albaquept soil. Pak J Bio Sci 5(5): 533536.

4. Syed MHZ (2014). Edible oil imports in Pakistan. South Asian J Manag Sci 8(1): 1-8.

5. Razi S (2014). Edible oil imports in Pakistan. South Asian J Manag Sci 8(1): 24-27.

6. Chaves LHG, Guerra HOC, Campos VB, Pereira WE \& Ribeiro PHP (2014). Biometry and water consumption of sunflower as affected by NPK fertilizer and available soil water content under semiarid Brazilian conditions. Agric Sci 5(4): 668-676.

7. Diazzorita M \& Grosso GA (2000). Response of sunflower to sources and levels of sulfur under semi-arid conditions. Int J Agric Biol 4(2): 155159.

8. Zubillaga MM, Mercau JL \& Lavado RS (2000). Response of sunflower to different levels of sulfur and planting pattern. Int. H. Echeverria (eds.), Proc $17^{\text {th }}$ Soil Sci Argentine Congress Mar Del Plata Argentina 15-20.

9. Ayub M, Tanveer A, Amin MZ, Sharar MS \& Pervaiz A (2002). Effect of different sources and levels of potassium on yield and oil content of spring sunflower. Pak J Biol Sci 2(3): 801-803.

10. Ahmad M, Nadeem MA, Ayub R \& Javaid F (2001). Response of sunflower to different potassium levels and harvesting times. Pak J Life Soc Sci 1(1): 45-47.

11. Havlin JL, Beaton JD, Tisdale SL \& Nelson WL (2004). Soil fertility and fertilizers: An introduction to nutrient management. 6: 196-216.

12. Fournier JM, Roldan AM, Sanchez C, Alexandre G \& Benlloch M (2005). $\mathrm{K}^{+}$ starvation increases water uptake in whole sunflower plants. Plant Sci 168: 823-829.
13. Asif M, Hussain N \& Khan MB (2001). Effect of $\mathrm{K}$ on the growth and seed yield of spring sunflower (Helianthus annuus L.). Pak J Biol Sci 4(1): 100-101.

14. Wani KK, Roy M \& Kassel SAG (2001). Fertilizing for high yield and quality sunflower IPI Bulletin No. 10. Intern Oil Seed Inst Switzerland.

15. Demurin, Y, Skoric D, Veresbaranji I \& Jocic $S$ (2001). Inheritance of increased oleic acid content in sunflower seed oil. Afri J Biotech 23(2): 87-92.

16. Bhagat DP, Padamani DR, Polara KB, Parmar KB \& Babaria NB (2005). Effect of different level of sulfur and potassium on growth, yield and yield attributes of sunflower. Asian J Soil Sci 5(1): 2062018.

17. Manaf A \& Hassan F (2006). Effects of sulfur on fatty acid accumulation in brassica cultivars. Int J Agric Bio 5(1): 588-592.

18. Rani K, Sharma KL, Nagasri K, Srinivas K, Murthy VT, Maruthi GR, Korwai H \& Grace J (2009). Response of sunflower to sources and levels of sulfur under rainfed semi-arid tropical conditions. Commu Soil Sci Plant Anal 40: 2926-2944.

19. Hocking PM, Lopez MP, Quiroz F \& David S (2002). Response of sunflower to sources and levels of sulfur under semi-arid conditions. Int J Agric Biol 4(2): 311-322.

20. AOAC (1990). Official Methods of Analysis, $15^{\text {th }}$ ed. Association of Official and Analytical Chemists. Inc Virginia USA. 770-771.

21. Steel RGD \& Torrie JH (1984). Principles and procedure of statistics. $2^{\text {nd }}$ ed. Mc Graw Hill New York. pp. 46-49.

22. Soleimanzadeh $M \&$ Hussain MR (2010). Response of sunflower to drought stress under different potassium levels. World Appl Sci J 8(4): 443-448. 
23. Hassan FU, Hakim SA, Munaf A, Qadir $G$ \& Ahmad S (2007). Response of sunflower (Helianthus annuus L.) to sulfur and seasonal variations. Int $J$ Agric Biol 9(3): 499-503.

24. Sepher EM, Malakouti J \& Rasouli MH (2002). The effect of $\mathrm{K}, \mathrm{Mg}, \mathrm{S}$ and micronutrients on the yield and quality of sunflower in Iran. $17^{\text {th }}$ WCSS 14-21.

25. Ma AG, Zhan ZL, Zhen P \& Fan LP (2001). The effect of potassium fertilizer in super high yield sunflower fields. $J$ Henan Agric Sci 9: 24-25.

26. Singh VL, Jhorar RK \& Chaudri V (2000). Interaction of sulfur with phosphorus and potassium in sunflower nitration in calcareous soil. Indian $J$ Plant Physiol New Ser 1: 21-27.

27. Ramzan MT (2000). Effect of different doses of potassium on yield and oil content of sunflower. MSc Thesis Deptt Agron Uni Agric Faisalabad.
28. Mollashahi M, Ganjali H \& Fanaei H (2014). Effect of different levels of nitrogen and potassium on yield, yield components and oil content of sunflower. Intl J Farm and Alli Sci 2(1): 1237-1240.

29. Ma AG, Zhan ZL, Zhen P \& Fan LP (2001). The effect of potassium fertilizer in super high yield sunflower fields. $J$ Henan Agric Sci 9: 24-25.

30. Khan MJ, Siraj MN \& Sharjeel MJ (2003). Response of sunflower to different levels of sulfur. Pak J Soil Sci 22(4): 42-49.

31. Nasreen S \& Imamullhaq SM (2002). Effect of sulfur fertilizer on yield and nutrient uptake of sunflower crop in an Albaquept soil. Pak J Bio Sci 5(5): 533536.

32. Hitsudea K, Yamada M \& Klepker D (2005). Sulfur requirements of eight crops and acid content in sunflower seed oil. J Agric Sci 23(5): 87-92. 